\title{
THE USE OF THE INVERSE PROBLEM OF SPECTRAL ANALYSIS TO FORECAST TIME SERIES
}

A. I. Sedov, Nosov Magnitogorsk State Technical University, Magnitogorsk, Russian Federation, sedov-ai@yandex.ru

The paper proposes a new method to forecast time series. We assume that a time series is a sequence of eigenvalues of a discrete self-adjoint operator acting in a Hilbert space. In order to construct such an operator, we use the theory of solving inverse problems of spectral analysis. The paper gives a theoretical justification for the proposed method. An algorithm for solving the inverse problem is given. Also, we give an example of constructing a differential operator whose eigenvalues practically coincide with a given time series.

Keywords: inverse spectral problem; perturbation theory; time series.

\section{Introduction}

The problems on constructing time series models can have various forms and represent various stochastic processes. Let us consider the problem in the following statement. Consider a time series $\left\{t_{1}, t_{2}, \ldots, t_{n}, \ldots\right\}$. The problem is to construct a model to forecast the values of several future members of the time series based on several known members. This problem is widely known. There exist many different models to solve this problem with different degrees of accuracy. The author took the liberty to submit another method.

The model is constructed in the form of an operator such that the sequence of its eigenvalues coincides, in a sense, with a given time series.

\section{Construction of Model}

Let $T$ be a linear, discrete, self-adjoint, lower-bounded below operator having a nuclear resolvent and acting in a separable Hilbert space $H$. Suppose that the spectrum $\sigma(T)$ of the operator $T$ is simple. Enumerate the eigenvalues $\lambda_{n}$ of the operator $T$ in increasing order, $n=\overline{1, \infty}$. Let $v_{n}$ be eigenfunctions corresponding to $\lambda_{n}$ and orthogonalized in $H$, and $P$ be the bounded operator of multiplication on the function $p \in H$ acting in $H$. We choose the operator $T$, which is "good" and has properties convenient for our purposes. We search for the perturbed operator $T+P$ whose eigenvalues coincide with the given time series. Therefore, the considered problem on forecasting members of a time series is solved as the inverse problem of spectral analysis. Recovery of the potential of only one spectrum was proposed by V. A. Sadovnichy and V. V. Dubrovsky in [1]. V. V. Dubrovsky and later his students proved the existence of the solution of the inverse problem of spectral analysis for various problems, including applied ones. Algorithms for numerical solution of inverse problems were developed [2-5].

The paper [2] shows that if the sum of a series $\sum_{n}\left|\lambda_{n}-\xi_{n}\right|$ is a sufficiently small number, then there exists a unique operator $T+P$ such that its spectrum $\sigma(T+P)=\left\{\mu_{n}\right\}$ coincides with the given sequence $\left\{\xi_{n}\right\}$. In order to ensure the conditions imposed on the sequence $\left\{\xi_{n}\right\}$, we switch from the sequence $\left\{t_{n}\right\}$ to the sequence $\left\{\xi_{n}\right\}, \xi_{n}=\lambda_{n}+\varepsilon t_{n}$, with $n \leq m$ and $\xi_{n}=\lambda_{n}$ with $n>m$, where $m$ is the number of the first members of the time series 
taking into account to obtain the forecasting, and a small number $\varepsilon$ is chosen to ensure the requirement that the sum of the series is small.

According to [2] and [3], in order to solve the inverse problem of spectral analysis, it is necessary to solve the following nonlinear equation:

$$
p=\alpha_{0}-\alpha(p)
$$

where

$$
\begin{gathered}
\alpha_{0}=\sum_{n=1}^{m}\left(\xi_{n}-\lambda_{n}\right) \varphi_{n}, \quad \alpha(p)=\sum_{k=2}^{\infty} \alpha_{n}^{(k)}(p) \varphi_{n}, \\
\alpha_{n}^{(k)}(p)=\frac{(-1)^{k}}{2 \pi i k} \int_{\left|\lambda-\lambda_{k}\right|=\frac{1}{2}\left(\lambda_{k+1}-\lambda_{k}\right)} S p\left[\left(P R_{0}(\lambda)\right)^{k}\right] d \lambda,
\end{gathered}
$$

$R_{0}$ is the resolvent of the operator $T$, and $\left\{\varphi_{n}\right\}$ is an orthonormal basis of the space $H$.

A number of papers (for example, [2] and [3]) uses the principle of compressing mappings to show that this equation has a solution. The paper [4] gives a convenient algorithm to find a solution to this equation. Let us give this algorithm.

Set the accuracy $\delta$.

1. Arbitrarily choose $m$ taking into account that the larger $m$ is, the more accurately approximate solution is obtained. If the number of $\xi_{n}$ is finite, then $m$ is defined in a natural way.

2. Set $p_{0} \equiv 0$.

3. $p_{1}=\alpha_{0}-\alpha\left(p_{0}\right)=\alpha_{0}$,

$$
\alpha_{0}=\sum_{n=1}^{m}\left(\xi_{n}-\lambda_{n}\right) \varphi_{n} .
$$

4. Calculate $p_{j+1}=\alpha_{0}-\alpha\left(p_{j}\right), j=1,2, \ldots$, by the following formulas:

$$
\begin{gathered}
\alpha(p)=\sum_{n=1}^{m}\left(\alpha_{n}^{2}(p)+\alpha_{n}^{3}(p)+\alpha_{n}^{4}(p)\right) \varphi_{n}, \\
\alpha_{n}^{2}(p)=-\sum_{i \neq n} \frac{V_{i n}^{2}}{\lambda_{i}-\lambda_{n}}, \quad V_{n i}=\left(P v_{n}, v_{i}\right) ; \quad \alpha_{n}^{3}(p)=\sum_{i, j \neq n} \frac{V_{n i} V_{i j} V_{j n}}{\left(\lambda_{i}-\lambda_{n}\right)\left(\lambda_{j}-\lambda_{n}\right)}-\sum_{i \neq n} \frac{V_{n i}^{2} V_{n n}}{\left(\lambda_{i}-\lambda_{n}\right)^{2}} ; \\
\alpha_{n}^{4}(p)=-\sum_{i, j, k \neq n} \frac{V_{n i} V_{i j} V_{j k} V_{k n}}{\left(\lambda_{i}-\lambda_{n}\right)\left(\lambda_{j}-\lambda_{n}\right)\left(\lambda_{k}-\lambda_{n}\right)}+\sum_{i, j \neq n} \frac{V_{n n} V_{n i} V_{i j} V_{j n}}{\left(\lambda_{i}-\lambda_{n}\right)\left(\lambda_{j}-\lambda_{n}\right)^{2}}+ \\
+\sum_{i, j \neq n} \frac{V_{n n} V_{n i} V_{i j} V_{j n}}{\left(\lambda_{i}-\lambda_{n}\right)^{2}\left(\lambda_{j}-\lambda_{n}\right)}+\sum_{i, j \neq n} \frac{V_{n i}^{2} V_{j n}^{2}}{\left(\lambda_{i}-\lambda_{n}\right)^{2}\left(\lambda_{j}-\lambda_{n}\right)}-\sum_{i \neq n} \frac{V_{n n}^{2} V_{n i}^{2}}{\left(\lambda_{i}-\lambda_{n}\right)^{3}} .
\end{gathered}
$$

5. Calculate $\mu_{n}, n=\overline{1, m}$ :

$$
\mu_{n}=\lambda_{n}+V_{n n}+\alpha_{n}^{2}(p)+\alpha_{n}^{3}(p)+\alpha_{n}^{4}(p)
$$


6. Compare the numbers obtained in Step 5 with the numbers $\xi_{n}$ using some criterion, for example, the least squares criterion:

$$
M N K=\sum_{n=1}^{m}\left|\xi_{n}-\mu_{n}\right|^{2}<\delta^{2} .
$$

7. If the criterion value is decreased in comparison with the previous one, then we go to the next iteration, i.e. to Step 4. If the value is increased, and the required accuracy was achieved at the previous iteration, then an approximate solution $\tilde{p}=p_{j+1}$ is found. If the value is increased, but necessary accuracy was not achieved at the previous iteration, then increase $m$ and go to Step 1.

\section{Example}

As an example, consider the time series defined by the IMOEX index of the Moscow Exchange at the time of closing in the period from January 03, 2019 to January 31, 2019 inclusive.

$$
\left\{t_{n}\right\}_{n=1}^{20}=\{2375.60 ; 2406.46 ; 2389.64 ; 2414.04 ; 2434.06 ; 2444.31
$$

$2440.00 ; 2439.35 ; 2434.39 ; 2447.38 ; 2473.33 ; 2467.90$;

$2468.35 ; 2491.02 ; 2481.5 ; 2497.58 ; 2476.06 ; 2497.41 ; 2510.65 ; 2519.27\}$.

Construct the sequence $\left\{\xi_{n}\right\}, \xi_{n}=0,000001 t_{n}+n^{2}$. As the operator $T$, we consider the Sturm-Liouville operator acting in the space $L_{2}=L_{2}(0, \pi)$ and generated by the boundary value problem

$$
-y^{\prime \prime}(x)=\lambda y(x), \quad y(0)=y(\pi)=0 .
$$

The eigenvalues $\lambda_{n}=n^{2}$ of the operator correspond to eigenfunctions $v_{n}(x)=\sqrt{\frac{2}{\pi}} \sin (n x)$ that are orthonormal in $L_{2}, n=\overline{1, \infty}$. We search the function $p$ as a series by the system of functions $\left\{\frac{1}{\sqrt{\pi}}\right\} \cup\left\{\sqrt{\frac{2}{\pi}} \cos (n x)\right\}_{n=1}^{\infty}$, which is orthonormal in $L_{2}(0, \pi)$. Choose $\varphi_{n}(x)=\sqrt{\frac{2}{\pi}} \cos (2 n x), n=\overline{1, \infty}$ as a basic function.

According to the algorithm, we find the function

$$
\begin{gathered}
p(x)=-0.04751203003 \cos (2 x)-0.04813001308 \cos (4 x)-0.04828264520 \cos (8 x)- \\
-0.04779380888 \cos (6 x)-0.04868302968 \cos (10 x)-0.04888900593 \cos (12 x)- \\
-0.04880299289 \cos (14 x)-0.04879099718 \cos (16 x)-0.04869201104 \cos (18 x)- \\
-0.04895283575 \cos (20 x)-0.04947222468 \cos (22 x)-0.04936500858 \cos (24 x)- \\
-0.04937461752 \cos (26 x)-0.04982980499 \cos (28 x)-0.04964198598 \cos (30 x)- \\
-0.04996457862 \cos (32 x)-0.04953616847 \cos (34 x)-0.04996698867 \cos (36 x)- \\
-0.05023713079 \cos (38 x)-0.05042192196 \cos (40 x) .
\end{gathered}
$$

Add the term $-0.05042192196 \cos (42 x)$ to this function and calculate $\left\{\mu_{n}\right\}_{n=1}^{21}$ according to the formula of Step 5. Then go back to the original data scale $\eta_{n}=100000\left(\mu_{n}-n^{2}\right)$,

$$
\left\{\eta_{n}\right\}_{n=1}^{21}=\{2375.60 ; 2406.50 ; 2389.69 ; 2414.09 ; 2434.11 ; 2444.37
$$

$$
2440.06 ; 2439.41 ; 2434.46 ; 2447.44 ; 2473.40 ; 2467.98 ; 2468.44 ; 2491.12 \text {; }
$$

$2481.69 ; 2497.73 ; 2476.23 ; 2497.63 ; 2511.00 ; 2519.94 ; 2519.40\}$.

The least squares criterion for the sets $\left\{\eta_{n}\right\}_{n=1}^{20}$ and $\left\{t_{n}\right\}_{n=1}^{20}$ is 1,95 . The forecasted value $\eta_{21}$ differs from the real $t_{21}$ by 2.3 , and the relative error is 0.0009 . 


\section{References}

1. Dubrovskiy V. V., Sadovnichiy V. A. [To the Substantiation of the Method of Calculating the Eigenvalues of a Discrete Operator using Regularized Traces]. Joint sessions of the Petrovskii Seminar on differential equations and mathematical problems of physics and the Moscow Mathematical Society (Thirteenth session, 2-5 February 1990). Russian Mathematical Surveys, 1990, vol. 45, issue 4, p. 120. (in Russian).

2. Sedov A. I. Existence and Uniqueness of the Solution of the Inverse Spectral Analysis Problem for a Self-Adjoint Discrete Operator. Bulletin of the South Ural State University. Series: Mathematical Modelling, Programming and Computer Software, 2008, no. 27 (127), issue 2, pp. 100-103. (in Russian).

3. Sedov A. I. About the Approximate Solution of the Inverse Problem of the Spectral Analysis for Laplace Operator. Bulletin of the South Ural State University. Series: Mathematical Modelling, Programming and Computer Software, 2010, no. 16 (192), issue 5, pp. 73-78. (in Russian).

4. Sedov A. I. About the Inverse Problem of the Spectral Analysis. Bulletin of the South Ural State University. Series: Mathematical Modelling, Programming and Computer Software, 2011, no. 4 (221), issue 7, pp. 91-99. (in Russian).

5. Zakirova G. A., Kirillov E. V. The Existence of Solution of the Inverse Spectral Problem for Discrete Self-adjoint Semi-bounded from Below Operator. Journal of Computational and Engineering Mathematics, 2015, vol. 2, no. 4, pp. 95-99. DOI: $10.14529 /$ jcem150410.

Andrey I. Sedov, PhD (Math), Associate Professor, Department of Mathematics, Nosov Magnitogorsk State Technical University (Magnitogorsk, Russian Federation), sedovai@yandex.ru.

Received February 25, 2019.

УДК 517.984.64

DOI: $10.14529 /$ jcem190108

\section{ПРИМЕНЕНИЕ ОБРАТНОЙ ЗАДАЧИ СПЕКТРАЛЬНОГО АНАЛИЗА ДЛЯ ПРОГНОЗИРОВАНИЯ ВРЕМЕННЫХ РЯДОВ}

\section{А. И. Седов}

В работе предлагается новый метод прогнозирования временных рядов. Будем полагать, что данный временной ряд является последовательностью собственных чисел некоторого дискретного самосопряженного оператора, действующего в гильбертовом пространстве. При построении такого оператора опираемся на теорию решения обратных задач спектрального анализа. В работе дано теоретическое обоснование предложенного метода. Приводится алгоритм решения обратной задачи. Приводится пример построения дифференциального оператора, собственные числа которого практически совпадают с данным временным рядом.

Ключевые слова: обратная спектральная задача; теория возмущений; временной ряд. 


\section{Литература}

1. Дубровский, В. В. К обоснованию метода вычислений собственных чисел дискретного оператора с помощью регуляризованных следов / В. В. Дубровский, В. А. Садовничий // Совместные заседания семинара имени И.Г. Петровского по дифференциальным уравнениям и математическим проблемам физики и Московского математического общества (тринадцатая сессия, 2-5 февраля 1990 г.). Успехи математических наук. - 1990. - Т. 45, вып. 4 (274). - С. 120.

2. Седов, А. И. О существовании и единственности решения обратной задачи спектрального анализа для самосопряженного дискретного оператора / А. И. Седов // Вестник ЮУрГУ. Серия: Математическое моделирование и программирование. 2008. - № 27 (127), вып. 2. - С. 100-103.

3. Седов, А. И. О приближенном решении обратной задачи спектрального анализа для степени оператора Лапласа / А. И. Седов // Вестник ЮУрГУ. Серия: Математическое моделирование и программирование. - 2010. - № 16 (192), вып. 5. C. $73-78$.

4. Седов, А. И. Об обратной задаче спектрального анализа / А. И. Седов // Вестник ЮУрГУ. Серия: Математическое моделирование и программирование. - 2011. № 4 (221), вып. 7. - С. 91-99.

5. Zakirova, G. A. The Existence of Solution of the Inverse Spectral Problem for Discrete Self-adjoint Semi-bounded from Below Operator / G. A. Zakirova, E. V. Kirillov // Journal of Computational and Engineering Mathematics. - 2015. - V. 2, № 4. P. 95-99.

Седов Андрей Иванович, кандидат физико-математических наук, дочент, доцент кафедры высшей математики, Магнитогорский государственный технический университет им. Г. И. Носова (Магнитогорск, Российская Федерачия), sеdоvai@yandex.ru.

Поступила в редакиию 25 февраля 2019 г. 